\title{
Development Of Quality Oriented Model For Restructuring Of Pre-Service Teacher Education Programs
}

\author{
Iffat Basit ${ }^{1}$, Qurat ul Ain ${ }^{2}$, Wajeeeha Kanwal ${ }^{3}$ \\ ${ }^{1}$ Balouchistan University of Engineering and Technology, Khuzdar, Pakistan \\ ${ }^{2}$ Balouchistan University of Engineering and Technology, Khuzdar, Pakistan \\ "Corresponding author: wajihakanwal311@gmail.com
}

\begin{abstract}
This study was premeditated to develop quality oriented model for restructuring of existing pre-service teacher education programs. Population of the study was comprised of all teacher educators and prospective teachers of teacher education institutions of Punjab and Islamabad, Pakistan. Stratified random sampling technique was used to select sample of 300 teacher educators and 890 prospective teachers from 30 institutions. Two research questionnaires were used for data collection. Results revealed that prospective teachers enrolled in Bachelor of Education (Honors) were dissatisfied with the institutional environment, practical work, assessment techniques and features of teacher education. Whereas prospective teachers enrolled in Bachelor of Education one year program showed dissatisfaction with program duration. that teacher Educators teaching at Bachelor of Education (Honors) expressed dissatisfaction about physical resources, teachers' competencies, teaching strategies, assessment techniques, professional skills, appreciative features of programs and institutional efforts to raise quality of the programs. Prospective teachers and teacher educators associated with both programs somewhat expressed similar opinions regarding quality of the programs. It is, therefore, recommended that teacher education institutions may improve the quality of both programs by incorporating suggestions highlighted in hypothetical "Model for Restructuring of Pre-Service Teacher Education Programs", keeping in view quality related concerns of the teacher educators and prospective teachers.
\end{abstract}

KEYWORDS

Quality, Re-Structuring of Education, Teacher Education, Prospective Teachers, Teacher Educators.

JOURNAL INFO

HISTORY: Received: August 25, 2021

Accepted: September 21, 2021

Published:.September 30, 2021

\section{INTRODUCTION}

Teaching is certainly an intricate job as it is much beyond the grasping subject knowledge and transmitting it to learners. Besides attaining insightfulness in subject it encompasses communicative and managerial skills in order to align and organize all learning activities with the content to be taught and can provide useful feedback adequately to the learners for further improvements. An effective teacher is expected to be receptive and responsive to learners in order to help them in resolving their problems and satisfying their educational needs so that a conducive learning environment can be established with in the classroom where students find them motivated, passionate, enthusiastic, self-interested towards studies and can enhance the horizon of their learning with the cooperation collaboration and effective guidance of their teacher (Rubio, 2009).

Teacher education is a program that is related to the development of teacher proficiency and competence that would enable and empower the teacher to meet the requirements of the profession and face the challenges therein. According to Goods Dictionary of Education, Teacher education means, "all the formal and non-formal activities and experiences that help to qualify a person to assume responsibilities of a member of the educational profession or to discharge his responsibilities more effectively".

System of education exclusively gyrates around teachers therefore they are bestowed extreme and paramount status. Dominant role of a teachers in direly demand appropriate and sufficient training of them so that they can do just with their professional commitments as well as can meet the expectations of people from them as nation builder. Debate on a professional development of teachers has gained distinct eminence as teachers' professional quality and outcomes of students are associated with the quality of a teacher education. It is being considered as decisive factor to evaluate students' learning. Teaching is multifaceted and multifarious profession that demands intellectual work thus it cannot be accomplished by a person who is not given adequate training or relevant professional education.

Appropriate Teacher education not only certifies that teachers are and will remain skilled and competent, but it also ascertains that their motivation will not be lesson (Musset, 2009). The quality and extent of learner attainment and success is primarily determined by the competence, thoughtfulness, sensitivity and self- motivation of teacher as well the quality of training he receives in order to fulfill his professional responsibilities.

In Pakistan preliminary or pre-service teacher education is being offered in higher secondary education sector and university sector through Government Colleges of Elementary Teachers (GCETs), Government Colleges of Education, Institute of Education and Research (IER) and Departments of Educations in Universities.

\section{$(\mathrm{cc}) \mathrm{Er}^{\mathrm{B}}$}

This work is licensed under a Creative Commons Attribution 3.0 License. 
Excellence of education in Pakistan specifically in public sector is deliberated poor on the basis of multiple indicators. Generally, most threatening element to quality education is rote memorization as students are commonly guided by teachers to learn in order to reproduce learnt facts in examination (Hayes,1996; Jaffer, 2005). Furthermore, pedagogical methods and institutional environment do not persuade learners to get embroil in cognitive activities, consequently their critical thinking and creative skills couldn't develop (Government of Pakistan, 2006c, 2002a; Sultana, 2001; World Bank 2006).

Certainly it is obligatory to detect core causes that threaten quality of teacher education and to design programs to eradicate these issues. Ali (2011) stated problems that appears as intimidation to the quality of teacher education. According to the author key issue is that educational policies are not exclusively employed. In Pakistan teacher education is greatly communicated through programs which are usually funded by donor agencies like USAID therefore various programs have been originated across the country with the reciprocal collaboration of Government, university departments of education, institutions exists in private sector and non-governmental organizations. Though many groundbreaking and advanced stabs have been projected through programs, initiated by donor agencies but their long lasting and sustainable impact on quality of teacher education is hitherto a matter of criticism. Literature reveals that such programs usually emphasizes on quantitative aspect instead of qualitative attempts. Furthermore, lack of research studies in teacher education in Pakistan is also major concern that retards quality assurance in teacher education. (World Bank, 1996; Gulzar, Bari \& Ejaz, 2005; Government of Pakistan, 2002a, 2006a; 2009, 2004a).

\section{OBJECTIVES}

1. To analyze various components of current teacher education programs including B.Ed. \& B.Ed. Honors with respect to stake holders opinion in order to assess their existing quality.

2. To determine the problems, associated with existing teacher education programs.

3. To develop model in order to contribute in escalating the quality of existing pre-service teacher education programs

\section{METHODOLOGY}

Design of this study was descriptive cum analytical in nature in which various components of B.Ed. \& B.Ed. Honors were analyzed in order to determine their existing quality. Moreover, the opinion of prospective teachers and teacher educators who were associated with respective programs was also determined through self-developed questionnaires. In this regard following methodology was adopted.

\section{- POPULATION OF THE STUDY}

The population of the study was consist of

1. Teacher educators, teaching prospective teachers who were enrolled in respective programs at teacher education institutions located in Province Punjab.

2. Prospective teachers B.Ed. (1 year) and B.Ed. Honours (4 year) who were studying in teacher education institutions aiming to serve education sector in future as a teacher.

\section{- SAMPLE}

Stratified random sampling technique was used to determine sample of the study including prospective teachers and teacher educators. . Sampling strata were established on the basis of teacher education programs (B.Ed. and B.Ed. Honours) offered in public and private sectors institutions. Following is the detail of sample:

1. Sample of 300 teacher educators was selected from 30 teacher education institutions, including Government Colleges for Elementary Teachers (GCETs), Colleges of Education (GCEs) and University Departments of Education, Federal Colleges of Teacher Education working in province Punjab and Islamabad Capital Territory (ICT) Pakistan.

2. Sample of 30 prospective teachers from each institute, from each program (B.Ed. and B.Ed. Honours) was selected based on their availability and the program being offered (B.Ed. / B.Ed. Honours) in selected teacher education institutions in province Punjab and Islamabad Capital Territory (ICT) Pakistan. Total no of respondents were 890 .

\section{- TOOLS FOR DATA COLLECTION}

In this study, data was collected through following two distinctive self-developed research questionnaires:

1. Satisfaction of Prospective Teachers (SPT)

2. Satisfaction of Teacher Educators (STE)

\section{- ANALYSIS AND INTERPRETATION OF DATA}

Statistical techniques descriptive frequencies, mean, standard deviation, t-test and ANOVA were applied through SPSS to analyze data, collected through the administration of questionnaires. 


\section{RESULTS}

Table No. 1. Perception of Prospective Teachers Regarding Weak Areas of the B.Ed. Program (N=710)

Weak Areas of the B.Ed. Program

Not responded

Class room management skills are not taught

Not well planned

Curriculum is not according to upcoming requirements

Curriculum is not practicum focused

Not compatible with professional life

Short time duration for teaching practice

Less focus on teaching of professional competencies

Assignments and presentations are not evaluated satisfactorily

Teachers don't give proper time / not committed

No improvement in teaching skills

Inappropriate management

Examination system is not satisfactory

Lack of basic facilities (light, building)

Inappropriate curriculum

No use of technology

Incompetent teachers

Provided feedback is not satisfactory. Report after teaching practice in form of presentation should be included based on entire teaching experience, prospective teacher gained during teaching practice in school

Projectors should be used

Traditional teaching methods

Mental stress on students, strict behavior of teachers.

Course duration is short and curriculum is lengthy

Total

\section{2}

351

42

8

12

17

21

186

5

8

3

7

4

4

9

2

7

2

2

2

2

4

710
$\%$

49.2

1.6

5.9

1.1

1.6

2.4

2.9

26.1

.7

1.1

.4

1.0

.6

.6

1.3

.3

1.0

.3

.3

.3

.3

.6

99.4

Table no. 1 indicates the stance of the prospective teachers of B.Ed. program on the elements that seem undesirable to them and weaken quality of the program. The table includes the list of all inappreciative aspects of the program that students 
dislike the most. Response rate is approximately $50.8 \%$. The most inappreciative features includes that program is not well planned, not compatible with professional life, short time duration for teaching practice, lacks to impart professional competencies, teachers don't give proper time / not committed, examination system is not satisfactory, inappropriate curriculum, course duration is short and curriculum is lengthy etc.

\section{Table No. 2 Perception of Prospective Teachers Regarding Weak Areas of B.Ed. Honours Program (N=180)}

\begin{tabular}{|c|c|c|}
\hline Weak areas of the B.Ed. Honours Program & $f$ & $\%$ \\
\hline not responded & 61 & 33.8 \\
\hline Less technological usage that needs to be increased & 15 & 8.3 \\
\hline No all-encompassing planning & 19 & 10.5 \\
\hline Less focus on professional competencies & 40 & 22.2 \\
\hline not skill oriented & 9 & 5.0 \\
\hline incompetent teachers & 4 & 2.2 \\
\hline 4 year program duration is too long, it should be reduced to 2 years & 14 & 6 \\
\hline teachers are overburdened because of staff shortage & 7 & 3.9 \\
\hline $\begin{array}{l}\text { effective implementation of class room activities / classroom environment is not well } \\
\text { managed }\end{array}$ & 8 & 4.4 \\
\hline not compatible with professional life & 3 & 1.7 \\
\hline Total & 180 & 100.0 \\
\hline
\end{tabular}

Table no 2 indicates the opinions of the prospective teachers of B.Ed. Honours program regarding the components that seems undesirable to them. The table includes the list of all inappreciative aspects of the program that students dislike the most. Response rate is approximately $66 \%$. Keeping in view the inappreciative features prospective teachers suggest that technological usage must be increased, Extensive planning is needed. They say that program fails to impart professional competencies. Moreover, B.Ed. Honors is not skill oriented and teachers often remain overburdened because of staff shortage etc.

Table No. 3. Comparison of Mean and Standard Deviation of Teachers on STE for the variable Association with the Program $(\underline{N=230)}$

\begin{tabular}{|c|c|c|c|c|c|c|}
\hline \multirow[b]{2}{*}{ Subscales } & \multicolumn{2}{|c|}{$\begin{array}{l}\text { B.Ed. } \\
(\mathrm{N}-177)\end{array}$} & \multicolumn{2}{|c|}{$\begin{array}{l}\text { B.Ed. Honours } \\
\text { (N-53) }\end{array}$} & \multirow[b]{2}{*}{$\mathrm{t}$-value } & \multirow[b]{2}{*}{ p-valu } \\
\hline & M & SD & $\mathrm{M}$ & SD & & \\
\hline Physical Resources & 59.7 & 10.6 & 55.8 & 10.3 & 2.359 & .019 \\
\hline Human Resources & 60.0 & 13.0 & 55.5 & 3.8 & 2.224 & .027 \\
\hline Incentives & 3.3 & 4.0 & 2.8 & 5.1 & .916 & .361 \\
\hline Admission criteria for prospective teachers & 3.7 & 3.8 & 3.2 & 9.6 & .706 & .481 \\
\hline
\end{tabular}




\begin{tabular}{|c|c|c|c|c|c|c|}
\hline Curriculum & 39.0 & 4.4 & 39.0 & 1.1 & -.068 & .946 \\
\hline Teaching strategies & 33.4 & 9.8 & 30.6 & 4.0 & 1.811 & .050 \\
\hline Time duration & 3.7 & 1.2 & 3.7 & 6.0 & .022 & .983 \\
\hline Institutional environment & 28.9 & 4.3 & 28.0 & 7.6 & 1.406 & .161 \\
\hline Assessment techniques & 38.2 & 5.7 & 35.0 & 8.8 & 1.337 & .042 \\
\hline Professional skills & 37.6 & 6.7 & 35.9 & 12.4 & 1.632 & .014 \\
\hline Problems & 45.4 & 9.4 & 48.4 & 5.0 & -2.104 & .037 \\
\hline Quality indicators & 85.5 & 11.3 & 84.0 & 5.2 & .811 & .418 \\
\hline Trends at teacher education & 31.5 & 5.8 & 32.7 & 1.0 & -1.290 & .198 \\
\hline Prominent features of Teacher Education & & & & & & \\
\hline Programs & 21.3 & 4.9 & 19.9 & 4.1 & 1.774 & .047 \\
\hline Satisfaction with the quality of program & 149.4 & 1.1 & 149.4 & 43.4 & .083 & .934 \\
\hline $\begin{array}{l}\text { Institutional Efforts to raise Quality of Teacher } \\
\text { Education Programs }\end{array}$ & 6.9 & 9.7 & 2.30 & 3.8 & 3.363 & .001 \\
\hline Total & 648.3 & 47.9 & 628.9 & 5.15 & 2.636 & .009 \\
\hline
\end{tabular}

Table 3 shows satisfaction of teacher educators on STE concerning the quality of Teacher Education programs being offered in their institution either B.Ed. or B.Ed. Honours. Significant difference of opinion among teacher educators exists on over all research scale STE (.009) at $\mathrm{p} \geq 0.05$ level of significance. Table reveals that teacher educators associated with B.Ed. Honours are less satisfied with the overall quality of the program (628.9). Responses against each subscale indicates that Teacher educators associated with B.Ed. Honours are comparatively dissatisfied with the physical resources (55.8), competencies of human resources (55.5), teaching strategies (30.6), assessment techniques (35.0), professional skills (35.9), appreciative features of teacher education programs (19.9) and institutional efforts to raise quality of teacher education programs (2.3). Moreover they see more quality threatening problems in B.Ed. Honours (48.4). Whereas teachers teaching to B.Ed. students shown no major concern about the quality of the program.

Table No. 4.Program Wise Comparison of Mean and SD of Prospective Teachers on SPT (N=890)

\begin{tabular}{|c|c|c|c|c|c|c|}
\hline \multirow[t]{2}{*}{ Subscale } & \multicolumn{2}{|l|}{$\begin{array}{l}\text { B.Ed. } \\
(\mathrm{N}-710)\end{array}$} & \multicolumn{2}{|c|}{$\begin{array}{l}\text { B.Ed. Honour (N- } \\
180)\end{array}$} & \multirow[b]{2}{*}{ t-value } & \multirow[b]{2}{*}{ p-value } \\
\hline & M & SD & M & SD & & \\
\hline Physical resources & 59.4 & 7.4 & 57.8 & 10.6 & 1.51 & .131 \\
\hline Curriculum & 18.1 & 3.3 & 18.7 & 3.5 & -1.80 & .071 \\
\hline Teaching strategies & 30.4 & 6.4 & 36.6 & 10.6 & -5.9 & .000 \\
\hline Time duration & 2.8 & 1.0 & 2.9 & 1.1 & -1.4 & .150 \\
\hline Institutional environment & 37.1 & 4.9 & 38.4 & 5.0 & -2.4 & .015 \\
\hline
\end{tabular}




\begin{tabular}{|c|c|c|c|c|c|c|}
\hline Assessment techniques & 26.9 & 6.9 & 31.4 & 9.3 & -4.8 & .000 \\
\hline Output of the program & 87.2 & 4.4 & 87.7 & 4.4 & -.981 & .327 \\
\hline Features of teacher education & 19.7 & 7.1 & 23.7 & 11.7 & -3.4 & .001 \\
\hline Weaknesses of the program & 7.2 & 10.0 & 6.4 & 8.7 & .818 & .414 \\
\hline Total & 296.4 & 26.3 & 311.3 & 33.9 & -4.3 & .000 \\
\hline
\end{tabular}

Table 4 indicates program wise perception of satisfaction level of prospective teachers on research scale SPT. Significant differences of opinion among prospective teachers of B.Ed. and B.Ed. Honours is found on overall SPT (.000) at $p \geq$ 0.05 level of significance. It is explored that prospective teachers of B.Ed. Honours are comparatively dissatisfied with teaching strategies (30.4), institutional environment (37.1) and assessment techniques (26.9). They also believe that these programs are not conforming to the appreciative features of teacher education programs (22.6) with respect to skill learning, use of ICT, merging upcoming educational trends and adequate planning. Moreover no significant difference of opinion among prospective teachers of B.Ed. and B.Ed. Honors is found on subscale physical resources (.133), curriculum (.071), time duration (.150), practical work (.645), output of the program (.327) and weaknesses of the program (.414) at $p \leq 0.05$ level of significance.

Table No. 5. Comparison of Mean and Standard Deviation of Teachers on STE for the variable Association with the Program $(N=230)$

$\begin{array}{cc}\text { B.Ed. } & \text { B.Ed. Honours } \\ (\mathrm{N}-177) & (\mathrm{N}-53)\end{array}$

\begin{tabular}{|c|c|c|c|c|c|c|}
\hline Subscales & M & SD & M & SD & t-value & p-value \\
\hline Physical Resources & 59.7 & 10.6 & 55.8 & 10.3 & 2.359 & .019 \\
\hline Human Resources & 60.0 & 13.0 & 55.5 & 3.8 & 2.224 & .027 \\
\hline Incentives & 3.3 & 4.0 & 2.8 & 5.1 & .916 & .361 \\
\hline Admission criteria for prospective teachers & 3.7 & 3.8 & 3.2 & 9.6 & .706 & .481 \\
\hline Curriculum & 39.0 & 4.4 & 39.0 & 1.1 & -.068 & .946 \\
\hline Teaching strategies & 33.4 & 9.8 & 30.6 & 4.0 & 1.811 & .050 \\
\hline Time duration & 3.7 & 1.2 & 3.7 & 6.0 & .022 & .983 \\
\hline Institutional environment & 28.9 & 4.3 & 28.0 & 7.6 & 1.406 & .161 \\
\hline Assessment techniques & 38.2 & 5.7 & 35.0 & 8.8 & 1.337 & .042 \\
\hline Professional skills & 37.6 & 6.7 & 35.9 & 12.4 & 1.632 & .014 \\
\hline Problems & 45.4 & 9.4 & 48.4 & 5.0 & -2.104 & .037 \\
\hline Quality indicators & 85.5 & 11.3 & 84.0 & 5.2 & .811 & .418 \\
\hline Trends at teacher education & 31.5 & 5.8 & 32.7 & 1.0 & -1.290 & .198 \\
\hline
\end{tabular}




\begin{tabular}{|c|c|c|c|c|c|c|}
\hline Prominent features of Teacher Education Programs & 21.3 & 4.9 & 19.9 & 4.1 & 1.774 & .047 \\
\hline Satisfaction with the quality of program & 149.4 & 1.1 & 149.4 & 43.4 & .083 & .934 \\
\hline $\begin{array}{l}\text { Institutional Efforts to raise Quality of Teacher } \\
\text { Education Programs }\end{array}$ & 6.9 & 9.7 & 2.30 & 3.8 & 3.363 & .001 \\
\hline Total & 648.3 & 47.9 & 628.9 & 5.15 & 2.636 & .009 \\
\hline
\end{tabular}

Table 5 shows satisfaction of teacher educators on STE concerning the quality of Teacher Education programs being offered in their institution either B.Ed. or B.Ed. Honours. Significant difference of opinion among teacher educators exists on over all research scale STE (.009) at $p \geq 0.05$ level of significance. Table reveals that teacher educators associated with B.Ed. Honours are less satisfied with the overall quality of the program (628.9). Responses against each subscale indicates that Teacher educators associated with B.Ed. Honours are comparatively dissatisfied with the physical resources (55.8), competencies of human resources (55.5), teaching strategies (30.6), assessment techniques (35.0), professional skills (35.9), appreciative features of teacher education programs (19.9) and institutional efforts to raise quality of teacher education programs (2.3). Moreover they see more quality threatening problem in B.Ed. Honours (48.4). Whereas teachers teaching to B.Ed. students shown no major concern about the quality of the program. No significant difference of opinion among teacher educators either affiliated with B.Ed. or B.Ed. Honours exist on rest of the subscales.

\section{DISCUSSION AND CONCLUSION}

This study was aimed to develop quality oriented model for restructuring of pre-service teacher education programs specifically B.Ed. and B.Ed. . (Honors). programs in the province of Punjab and Islamabad. Responses of the prospective teachers of B.Ed. (Honors) revealed their dissatisfaction with the institutional environment, practical work assigned to them, assessment techniques used by their teachers to assess their performance, and features of teacher education program with respect to skill learning, use of ICT, merging upcoming educational trends and adequate planning. Therefore, they find more quality threatening problems related to the program. Though B.Ed. (Honors) is launched with anticipation to make teacher education more quality oriented and effective and to overcome shortcomings which are commonly associated with B.Ed. program but yet there are certain areas highlighted in the current study need to be focused to ensure the quality in B.Ed. (Honors).

It was discovered that teacher educators of B.Ed. (Honors) program are comparatively dissatisfied with the availability of sufficient physical resources. Further they have also expressed dissatisfaction of the professional competence of teacher educators, especially with teaching strategies and performance assessment techniques of prospective teachers. Along with this, teacher educators show concerns on inadequately planning, ICT skill orientations and effective tutorial support. However, teacher educators affiliated with B.Ed. program showed no major concern regarding the quality of the program. Sector wise comparison of teacher educators indicates that teacher educators teaching in public sector institutions are dissatisfied with the availability of physical resources. Similarly, they believed that teacher education programs being offered in public sector institutions are not compliant to the appreciative features of teacher education programs with respect to skill learning, use of ICT, merging upcoming educational trends and adequate planning. In contrast, teachers educators affiliated with the private sector institutions are relatively dissatisfied with the competencies of human resources, incentives provided to them for encouragement by their institutes, assessment techniques used to assess the performance of prospective teachers and efforts at institutional level in order to raise quality of teacher education programs.

Literature also supports the results of the present study. Quality of teacher education in Pakistan is recognized poor (Ali, 2011; Jaffer, 2005). Several research studies argued that professional development of teachers, students' learning and academic achievement are interconnected (Halai et al., 2004; Guskey \& Spark, 1996; Shah, 2000) yet quality of teacher education is usually affected due to shortage of facilities, budget constraints, ineffective managerial system, poor examination and assessment techniques and inappropriate supervision. Pre-service teacher education programs are of poor quality and directly affect the quality of education and cause its deterioration (Ahmed, 2009; Aga Khan University, 2002; Government of Pakistan, 2005 and 2002c; NEP, 2009). NEP (2009) has well captured the scenario: - The reform of teaching quality is of the highest priority. There is a consensus amongst all stakeholders that the quality of teachers in the public sector is unsatisfactory\| (p.43).

Educational Statistics Pakistan 2008-2009 indicate that more than 90 percent teachers serving in public schools are professionally trained but unluckily the impact of training either pre-service or in-service is perceptible, neither in their teaching nor in students' achievement. Thus, it reveals poor capacity building of prospective teachers. Number of independent research 
reports, policy documents and Government reports, numerous researches and documents carried out by donor funded projects etc. on teacher education system in Pakistan reveals various quality related issues and breaches, which impede effectiveness of teacher education programs (Asian Development Bank, 1992; Academy for Educational Development, 2005; Barber, 2010; Government of Pakistan, 2002b; Hoodbhoy 1998).

\section{RECOMMENDATION}

Keeping in view the findings and conclusion following are some of the recommendations of study:

1. Teaching strategies used by teacher educators to prepare future teachers may be improved and replaced with modern instructional techniques including group activities, direct instruction, concept teaching, classroom discussions, micro teaching, project based teaching, inquiry based teaching, web based teaching, role play etc.

2. Academic and professional progress of prospective teachers may not be confined to written examination but it should be assessed by alternative ways like observations, projects, portfolios, discussions, performance tasks, presentations etc.

3. Educational environment of the institution needs to be made conducive enough that promote personalized learning (self-learning) and every student should be valued and educated well so that he/she may share the burden of preparing upcoming human resources for the development of the country.

4. Curriculum of teacher education needs to be updated, more relevant to professional field, supportive for prospective teachers to cope up with such problems that being teacher may encounter them during classroom practices.

5. Time duration of program may neither be too long nor be too short thus it is recommended that it should be of two to three years.

6. Extensive teaching practice of about one session is recommended to be conducted in govt. institutions, evaluated by head of the institute. Moreover, it may be converted into internship; complimented with sufficient stipend, compulsory for all prospective teachers at the end of the program.

7. Teacher education programs are recommended to be featured with teaching learning skills, ICT education, upcoming trends of secondary education, incorporating modern teacher education trends and effective tutorial support etc. so that professional requirements can better be catered

8. Prospective teachers needs to be given command over professional skills like, instructional skills, managerial skills, communication skills and counseling skills etc.

9. Admission criteria for prospective teachers with respect to both programs are recommended to be revised.

10. Teacher education is recommended to focus on practical teaching instead of theoretical learning so that experience of professional field or actual classroom teaching may be provided to future teachers.

\section{MODEL FOR RESTRUCTURING OF PRE-SERVICE TEACHER EDUCATION PROGRAMS}

Teacher education needs to be related to actual professional life situations, requirements and aspirations of society. Panda \& Menon suggested reforms regarding the nature of teacher education institutions, selection and promotion procedures and structure, admission criteria and procedure for enrolment of prospective teachers, qualitative measures in order to improve pre-service teacher education, curriculum, teaching methods, skill training, pedagogical skill development through practice, research and development with reference to $21^{\text {st }}$ century are the need of time. In the light of literature reviewed and findings of the study comprised on stakeholders' perceptions, researcher developed model based on few important elements of teacher education that needs to be focused if improvement in teacher education programs is to be anticipated. See Figure 1.

\section{ADMISSION CRITERIA FOR PROSPECTIVE TEACHERS}

Teacher education institutions have to select limited candidates for teacher education programs among abundant of application received. Usually very simple admission criterion is followed in teacher education institutions in Pakistan. In fact teacher education programs in Pakistan are the one in which everyone can easily get enrolled. Purpose behind establishing criteria for admission is to choose suitable \& motivated people who can be elevated as committed and professional teachers in future. Few suggestions are being given in figure no 2 in order to make admission criteria strong for prospective teachers. It will help to select more appropriate individuals to train as future teachers, if followed properly.

Keeping in view the responses of respondents against open ended questions about admission criteria for prospective teachers some elements are suggested in figure 2. Explanation of suggested criteria is given below;

i. Qualification required for getting admission in teacher education programs should be increased from intermediate to graduation. Required result percentage should also be re-considered but emphasis may be given on abilities instead of secured marks percentage so that capable persons can be selected.

ii. Written test based on knowledge of core school subjects including English, Urdu, Islamic Studies, Pakistan Studies should be taken. Additionally science subjects should be added for science students. As these are compulsory school subjects and every teacher should be proficient in these. 
iii. Aptitude test should be administered to those who wanted to be enrolled in teacher education programs so that only appropriate people for the profession can be trained.

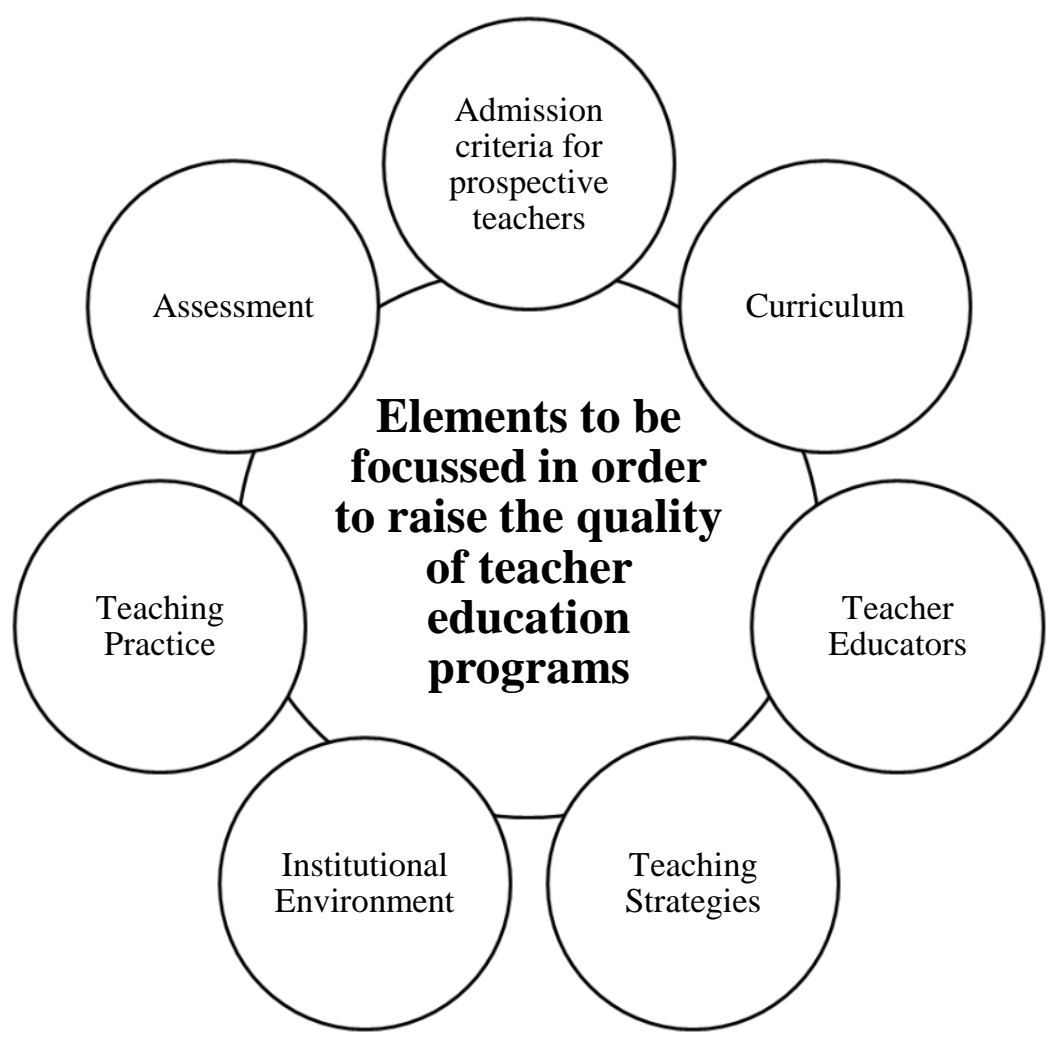

Figure 1. Proposed Model for Restructuring of Teacher Education Programs

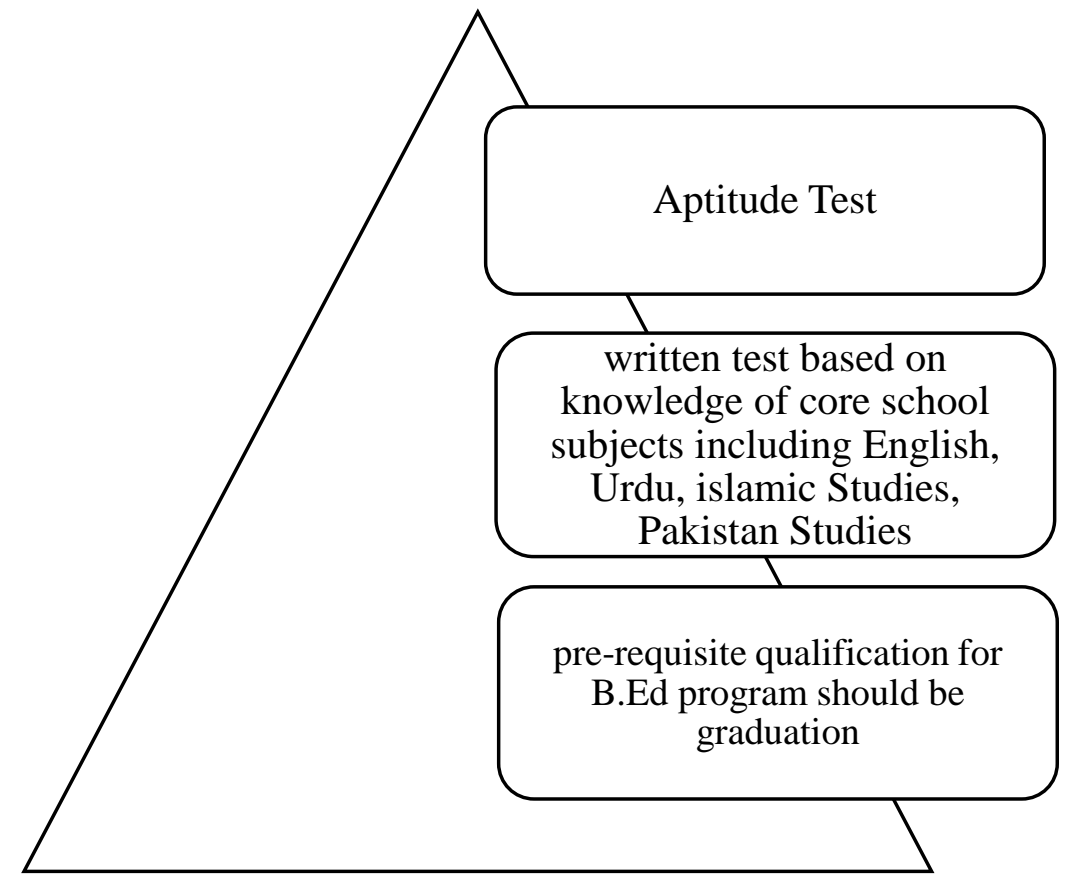

Figure 2. Suggested admission criteria 


\section{2- CURRICULUM}

Curriculum is also very significant component in education generally and in teacher education specifically. The National Academy of Education Committee on Teacher Education designed a framework that articulates core skills and concepts that are necessary to be included in the curriculum of teacher education. This framework is based on three fundamental dimensions of knowledge;

1- Knowledge about students, the way they learn and their social context

2- Understanding about curriculum, content to be taught, skills to teach, skills to be developed, goals and purposes of education to be met

3- Pedagogical or instructional knowledge, ability to handle learners with diversities, establish productive classroom environment.

Knowledge $\left\{\begin{array}{l}\cdot \text { content knowledge } \\ \cdot \text { instructional knowledge } \\ \cdot \text { testing and evaluation } \\ \cdot \text { handling of curriculum } \\ - \text { teaching laws } \\ - \text { education and its growing demands } \\ \text { role of education in development of indivial, and } \\ \text { society } \\ \text { guidence and councelling of students and parents } \\ \text { nurturing of potential in each individual }\end{array}\right.$

\begin{tabular}{|c|c|}
\hline Skills & $\begin{array}{l}\text { - reflective skills } \\
\text { - instructional or pedagogical skills } \\
\text { - communication skills (with students, collegues, } \\
\text { administration) } \\
\text { - manegerial skill (management of people, time, } \\
\text { instructional resources, content, intelligence and } \\
\text { emotions for handling diversity) } \\
\text { - self management (management of work \& time } \\
\text { schedules, personal life tasks ) } \\
\text { - Administrative skills } \\
\text { - technological skills } \\
\text { - innovation and creativity } \\
\text { life skills }\end{array}$ \\
\hline Attitude\&value & $\begin{array}{l}\text { - empathy } \\
\text { - moral and social values } \\
\text { - every child can learn } \\
\text { - professionalism (commitment towards profession) }\end{array}$ \\
\hline
\end{tabular}

Figure 3. Curriculum

This framework for the curriculum of teacher education is comprised on interaction among students, content and teaching. This interaction serve two major aims, first is sharing of knowledge, transmission of cultural heritage, fulfillment of social expectations as teaching profession is associated with technical and ethical aspirations. Second is to prepare future teachers to be the part of democratic world as they are expected to assume the responsibility of educating young people as 
productive member of society who can lead good political, economic, civic life in future (Hammond, 2006). Few suggestions about curriculum of teacher education are being given below in Figure 3. Competent and proficient teachers are need of hour so above mentioned aspects are proposed to be incorporated in curriculum of teacher education programs and future teachers are expected to be trained accordingly.

\section{3- TEACHER EDUCATORS}

Among various others, Teacher educators are also a crucial component of development and change in teacher education. Efforts are globally being initiated to ensure quality in teacher education through improving the quality of teacher educators who are responsible to teach teachers.

\begin{tabular}{|c|c|}
\hline \multirow[t]{2}{*}{ pedagogical skills } & $\begin{array}{l}\text { - } \text { reflection and cretivity } \\
\text { - content presentation } \\
\text { - interpersonal skills } \\
\text { - ability to develop passion about education } \\
\text { - command on various method of teaching and their } \\
\text { purposes } \\
\text { - ability to incorporate various teaching methods to ensure } \\
\text { variation } \\
\text { - ability to connect curiculum with its relevance to real life } \\
\text { - assessment of students academic and performance } \\
\text { - timely and constructive feedback }\end{array}$ \\
\hline & $\begin{array}{l}\text { - motivate and set high standards for students to achieve } \\
\text { - impart values and beliefs that are supportive to lead } \\
\text { successful personal and professional life } \\
\text { - ablity of classroom management } \\
\text { - facilitator and guide } \\
\text { - creative conducive environment of the classroom where } \\
\text { every student can freely participate, get engaged, \& } \\
\text { involved in learning activities }\end{array}$ \\
\hline $\begin{array}{l}\text { leadrship } \\
\text { and } \\
\text { manegerial skills }\end{array}$ & $\begin{array}{l}\text { - } \text { projects and assignments } \\
\text { cooperative learning (arrange and manage group } \\
\text { activities) } \\
\text { - experimentation with varied teaching approaches }\end{array}$ \\
\hline & $\begin{array}{l}\text { - } \text { guidence and councelling } \\
\text { - management of diversities among students } \\
\text { - plan and organize learning activities } \\
\text { - urge for self study and self development to be good } \\
\text { professioal } \\
\text { - familiarity with various learning styles and how to } \\
\text { manage them } \\
\text { - managing available instructional resources }\end{array}$ \\
\hline
\end{tabular}

Growing trend of integrating information communication technology in education has raised the essentiality of educating teacher educators as well. Studies conducted on education generally and on teacher education specifically with reference to Pakistan, identified that reason of poor quality of education is connected with the poor quality of general education of 
teachers themselves. Keeping in view the perceptions about the significance of teachers and their existing quality, it is in direly needed to improve their quality so that they can perform their role with true spirit as expected from them. Some suggestions are being given below

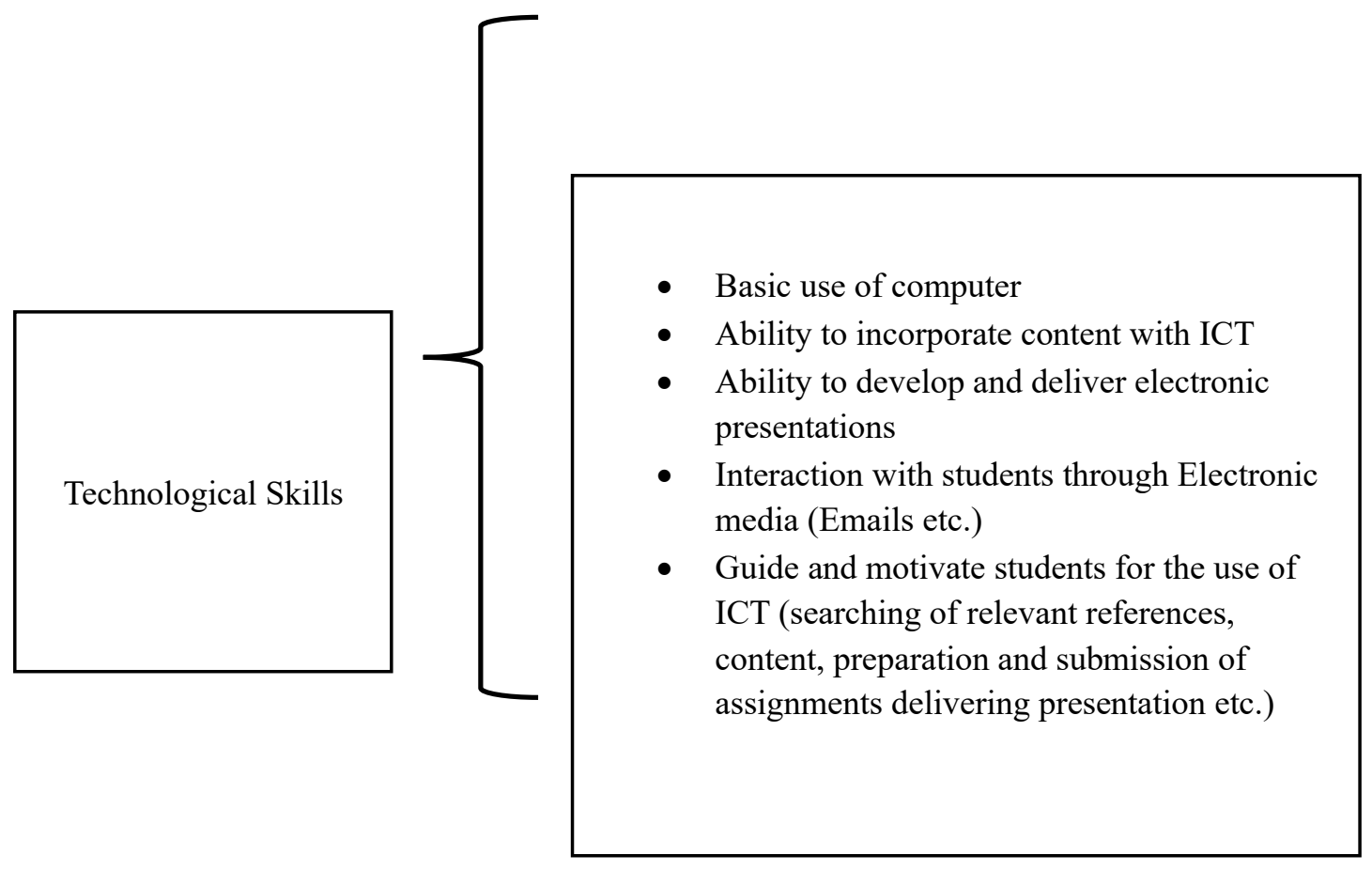

\section{Figure 4. Characteristics among teacher educators}

All above mentioned skills and attributes are necessary for teacher educators as they assume the responsibility of teaching future teachers. Teacher education is challenging profession thus teacher educators simultaneously have to be traditional and innovative. They have to consider national and international demands and trends of the profession. In order to fulfill the swiftly changing professional requirements, teacher educators need to be prepared accordingly.

\section{TEACHING STRATEGIES}

Quality of teaching has always been most debated issue in educational spheres. Instructional process can be more effective and meaningful if connected with real life situations and with the existing knowledge that students already possess. This point of view is based on constructivist approach and it facilitates teachers to deal with cultural and social diversities among students. Figure 5 indicates several teaching strategies some are content focused and some are learner centered. Keeping in view the nature of teacher education, prospective teachers should be proficient in using all these strategies. Thus it is suggested that all theoretical and experiential strategies of teaching should be taught (theoretically and practically) to future teachers so that they can cope with all types of learning situations. 


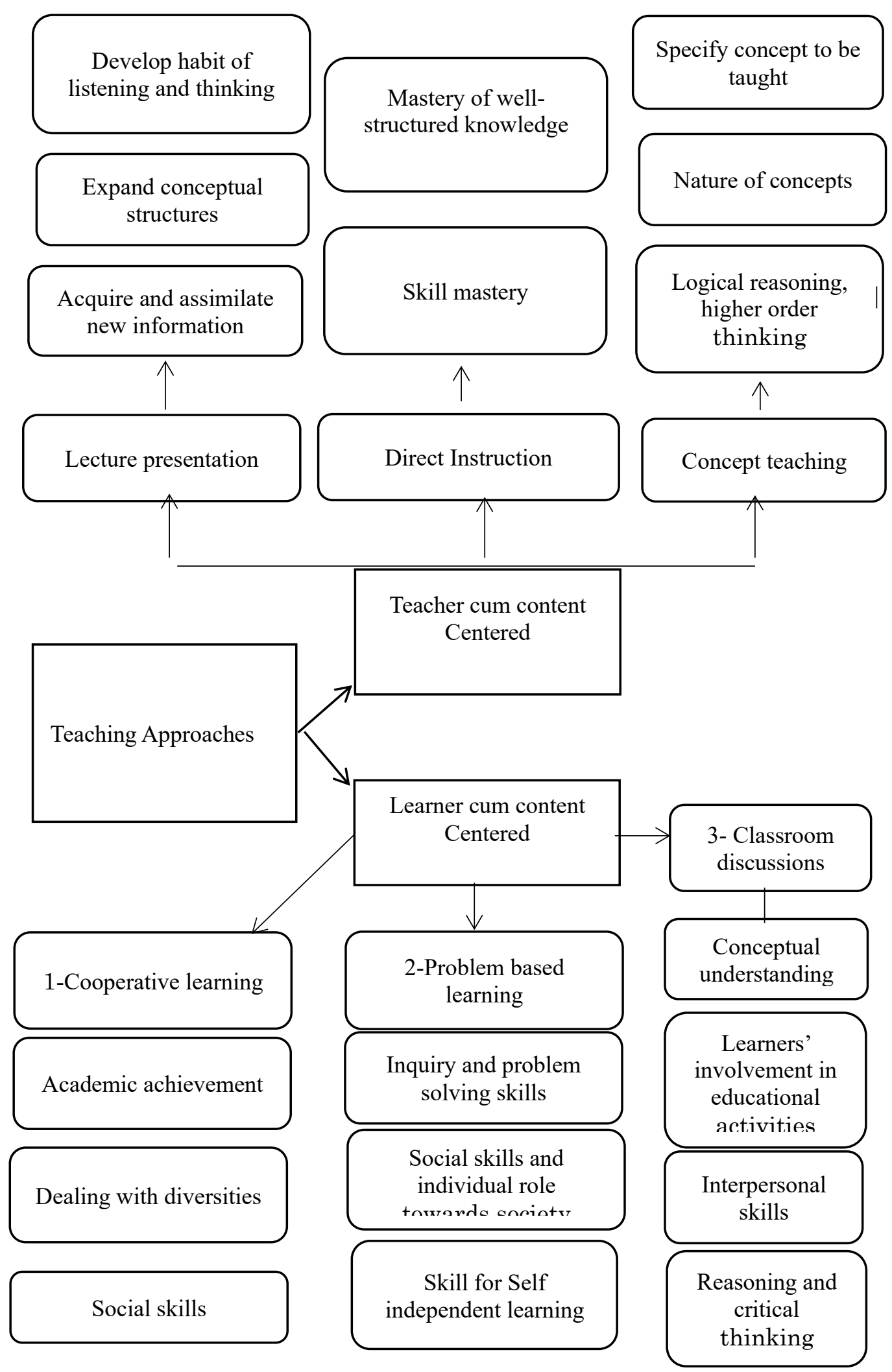

Figure 5. Teaching strategies extracted from models of teaching by Richard I. Arends. 


\section{4- INSTITUTIONAL ENVIRONMENT}

Institutional environment with reference to education refers to the environment where students and teachers have to work collaboratively in order to achieve educational goals. Educational environment includes two major dimensions related to institutional life including physical surroundings like cleanliness, condition of available facilities, sufficiency of building, classrooms, ventilation of classroom, available instructional materials and their working condition etc. other dimension in this regard is its conduciveness, how and to what extent students can be efficiently involved in educational activities and educational environment supports connectedness and communication between students, teacher and administration.

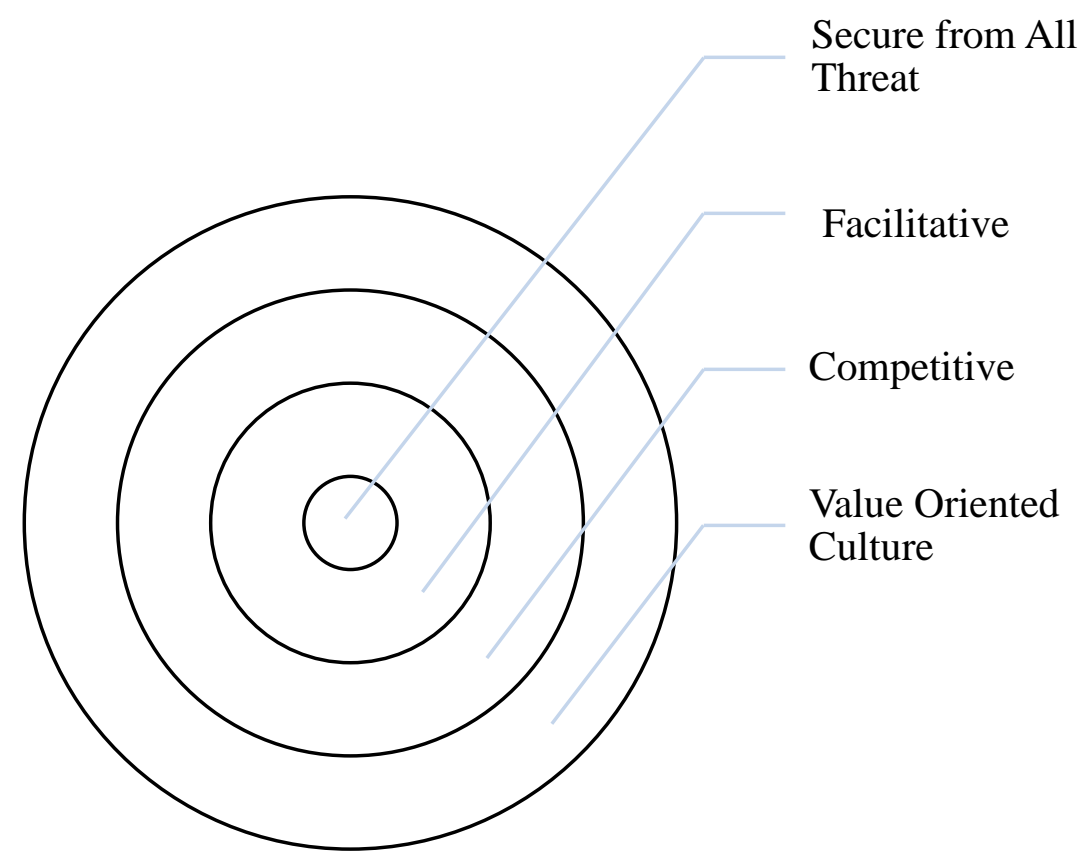

Figure 6. Attributes of institutional environment

Secure from all threats refers to elimination of racial, physical, emotional, ethnic etc. terrorizations. Every individual of the institution should feel free and secure so that they can entirely focus on their goals which bring them to that respective institution. It is the initial and basic component which is required to be ensured in any institution.

Facilitative environment refers to provision of required basic facilities including sufficient building, ventilated and adequately furnished classroom, safety from weather threats, availability of clean water etc. educational facilities like labs, laboratories, recorded lectures, instructional aids, experiential learning through practical activities concerning teaching, competent teachers, appropriate teaching strategies, and everything that can help promoting learning of prospective teachers. In short a facilitative environment is something suitable for living and learning of learners.

Competitive environment refers to dynamic institutional system which promotes self- learning, hard work among individuals and eagerness to achieve success. These elements are associated with motivation by administration and by teachers. Encouraging and responsive attitude of faculty and administration motivates learners to overcome their weakness and helps them to excel. Planning and execution of adequate educational activities either individual or group and constructive feedback about learners' progress can impart feeling of competition among them.

value oriented aspect is concerned with moral principles accepted by individuals and society i.e recognition of right and wrong, mutual respect, cooperation and respect of diversity among individuals associated with respective institution in any way. It also refers to equal allocation of resources within the institution. This is the responsibility of the administration and faculty of the institution to ensure practice of general values, discourage ethnic, social, racial prejudices and encourage habit of mutual respect and cooperation among individuals. 


\section{5- TEACHING PRACTICE}

Teaching practice is denoted for the practical implementation of knowledge and instructional strategies that student teachers learn in teacher education institutions. Purpose of teaching practice is to support future teachers to get prepare for teaching careers through incorporating them into real teaching learning atmosphere as they are the part of institution. This experience exposes reality of teaching to them and provides them chance to be innovative, creative and effective professional. (http://www.btc.uob.edu.bh/details.aspx?id=aff71af9-f862-e211-b5dd0022191ecece\& gid =3, retrieved on 18th December, 2005). Effective teaching practice influence professional grooming of prospective teachers. Influential teaching practice should view following consideration;

i. Encouraging good communication between teachers and learners

ii. Encouraging interaction among learners

iii. Providing opportunities for active participation

iv. Timely and appropriate response and feedback to trainee teachers

v. Emphasizing task on time

vi. Motivating learning by communicating expectations

vii. Respecting diverse talents and ways of learning

Teachers are known for reshaping individuals' personalities. They are to be trained enough so that they can do justice with their profession and can fulfill related expectations. Teaching practice is initial experience that teachers acquire during professional education so it must be well planned and organized.

Teaching Practice Should not be Formality for Acquiring Degree but Prove to Be the Nexus of

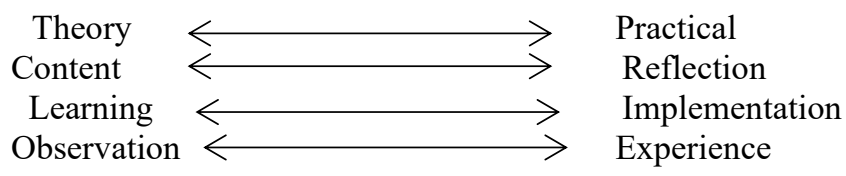

Diverse Ways of Practicum and Supportive Instructional Approaches

\begin{tabular}{|c|c|c|c|c|c|c|}
\hline $\begin{array}{l}\text { Diverse } \\
\text { Practicum }\end{array}$ & Purpose & \multicolumn{5}{|c|}{ Instructional Approaches } \\
\hline $\begin{array}{l}\text { Teaching } \\
\text { practice at } \\
\text { schools }\end{array}$ & $\begin{array}{l}\text { for experiencing } \\
\text { real professional } \\
\text { situation }\end{array}$ & $\begin{array}{l}\text { Activity } \\
\text { Based }\end{array}$ & Inquiry & $\begin{array}{c}\text { Self- } \\
\text { Directed }\end{array}$ & Reflection & $\begin{array}{c}\text { Experiential } \\
\text { learning/ } \\
\text { Problem } \\
\text { based }\end{array}$ \\
\hline $\begin{array}{l}\text { Micro } \\
\text { Teaching }\end{array}$ & for skill learning & $\begin{array}{c}\text { Didactic } \\
\text { demonstra- } \\
\text { tion } \\
\text { Modeling }\end{array}$ & $\begin{array}{l}\text { Simulation } \\
\text { and Role } \\
\text { playing }\end{array}$ & Reflection & $\begin{array}{l}\text { Active } \\
\text { learning }\end{array}$ & $\begin{array}{c}\text { Experiential } \\
\text { learning / } \\
\text { Problem } \\
\text { based }\end{array}$ \\
\hline $\begin{array}{l}\text { Apprentice } \\
\text { ship/ } \\
\text { Internship }\end{array}$ & $\begin{array}{l}\text { Apprenticeship/ } \\
\text { internship of } \\
\text { one year in } \\
\text { government } \\
\text { schools with } \\
\text { sufficient } \\
\text { stipend to } \\
\text { enable an } \\
\text { individual for } \\
\text { better career }\end{array}$ & $\begin{array}{l}\text { Experiential } \\
\text { learning }\end{array}$ & Reflection & $\begin{array}{c}\text { Self- } \\
\text { directed/ } \\
\text { Locus of } \\
\text { Control }\end{array}$ & $\begin{array}{l}\text { Collaborative } \\
\text { learning }\end{array}$ & Inquiry \\
\hline
\end{tabular}

Figure 7. Practicum aspired with respect to teacher education 
As it is reality known by all, that in Pakistan only practicum that is experienced by prospective teachers at the end of their program is teaching practice. As teacher education is skill oriented program thus it has to be more practice oriented. In this regard it is suggested that besides teaching practice at school, micro teaching and apprentice ship should also be initiated. Moreover teaching practice should be made more comprehensive, practical, natural and reliable. Internship or apprentice ship is more appreciative in reference to provide practical experience of teaching in natural setting. Furthermore micro teaching is recommended to be incorporated to possible extent if not completely so that student teachers can experience or observe learning of pedagogical skills.

\section{6- ASSESSMENT}

Teaching of teachers is very crucial job. One of the most significant areas in teacher education that needs to be focused and theoretical and empirical researches are to be conducted is assessment and evaluation (Soled, 1995). Productive, purposeful and varied evaluating strategies are becoming need of time in order to evaluate learning outcomes of teacher education. Hammond (2010) quoted Cochran-Smith who has identified three common ways that are currently being used to assess outcomes of teacher education. These include assessment through professional performance of prospective teachers, scores on written examination and performance during teaching practice (Hamond 2010).

Prospective teachers are now supposed to learn various teaching skills and strategies thus teacher educators should have refined knowledge and skills about assessment of learning of prospective teachers. They should also be familiar with various assessment strategies and how and when to employ these strategies to meet varied purpose of assessment (Hammond, 2010).

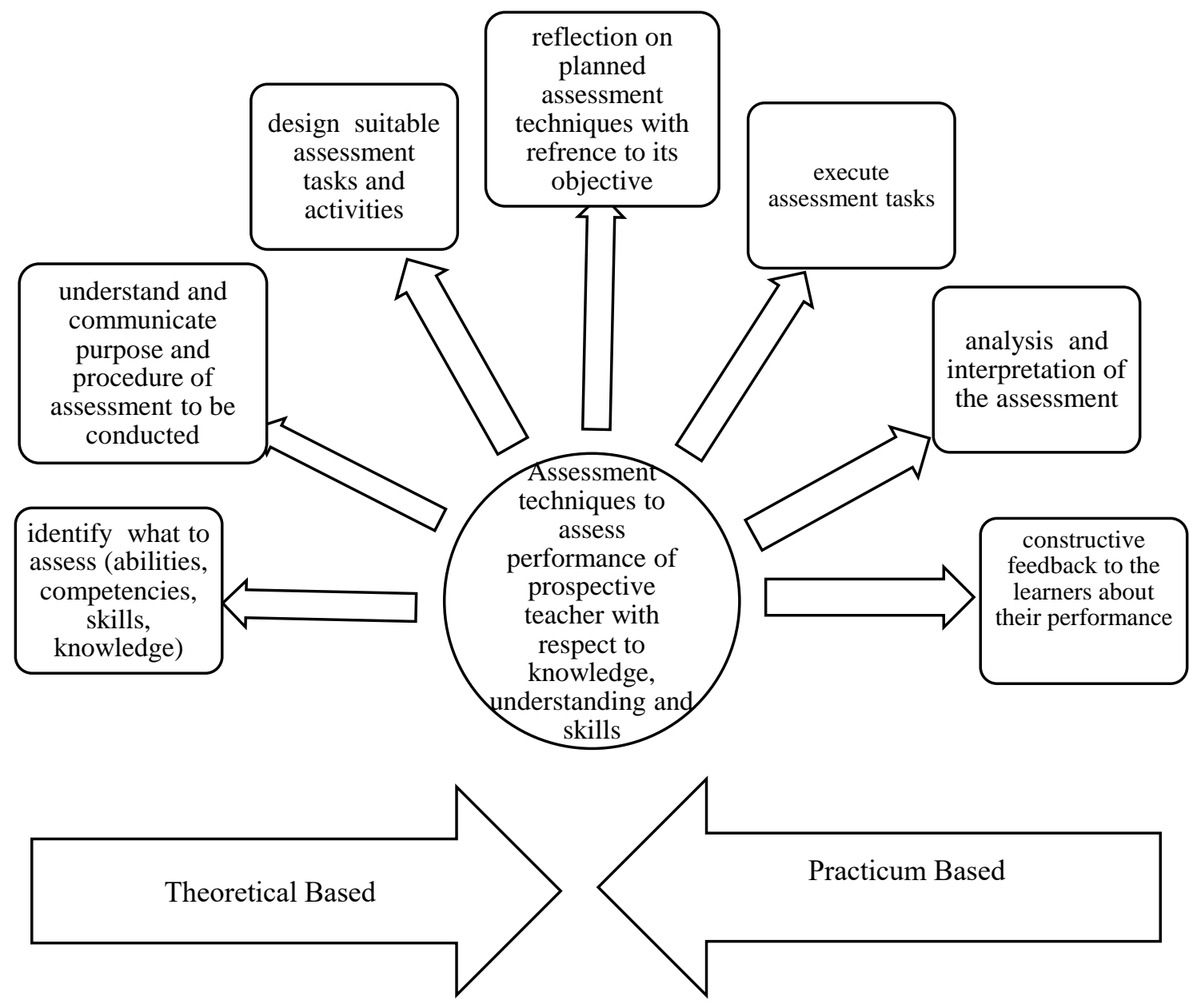

Figure 8. Assessment Techniques 
There is a great responsibility on the shoulders of teacher as being upholder of heritage which belongs to mankind and exclusive appropriator of novel and innovative knowledge. In current era, manifestation of unprecedented transformation of knowledge regarding all dimensions of worldly life is being tremendously increased thus scope of teacher education and role that teacher educators are expected to perform has been diversified and needs to be directed as it may commensurate with frequently changing environment and professional requirements (Panda \&Tewari, 2009).

Keeping in view the literature researcher developed model with the assumption that it will contribute in quality assurance at teacher education specifically for the training of secondary school teachers. On the basis of above discussed 'model for restructuring of pre-service teacher education programs', it is hypothesized that it can lead towards the improvement of teacher education programs if all its indicated components are emphasized, focused and incorporated in existing teacher education program either B.Ed. or B.Ed. Honours. Moreover, improvement in teacher education programs will ultimately leads towards the improvement of school education. The assumption related to model is well described in figure 9.

\section{Restructuring of Pre-service Teacher Education Programs through incorporating proposed measures in the area of}

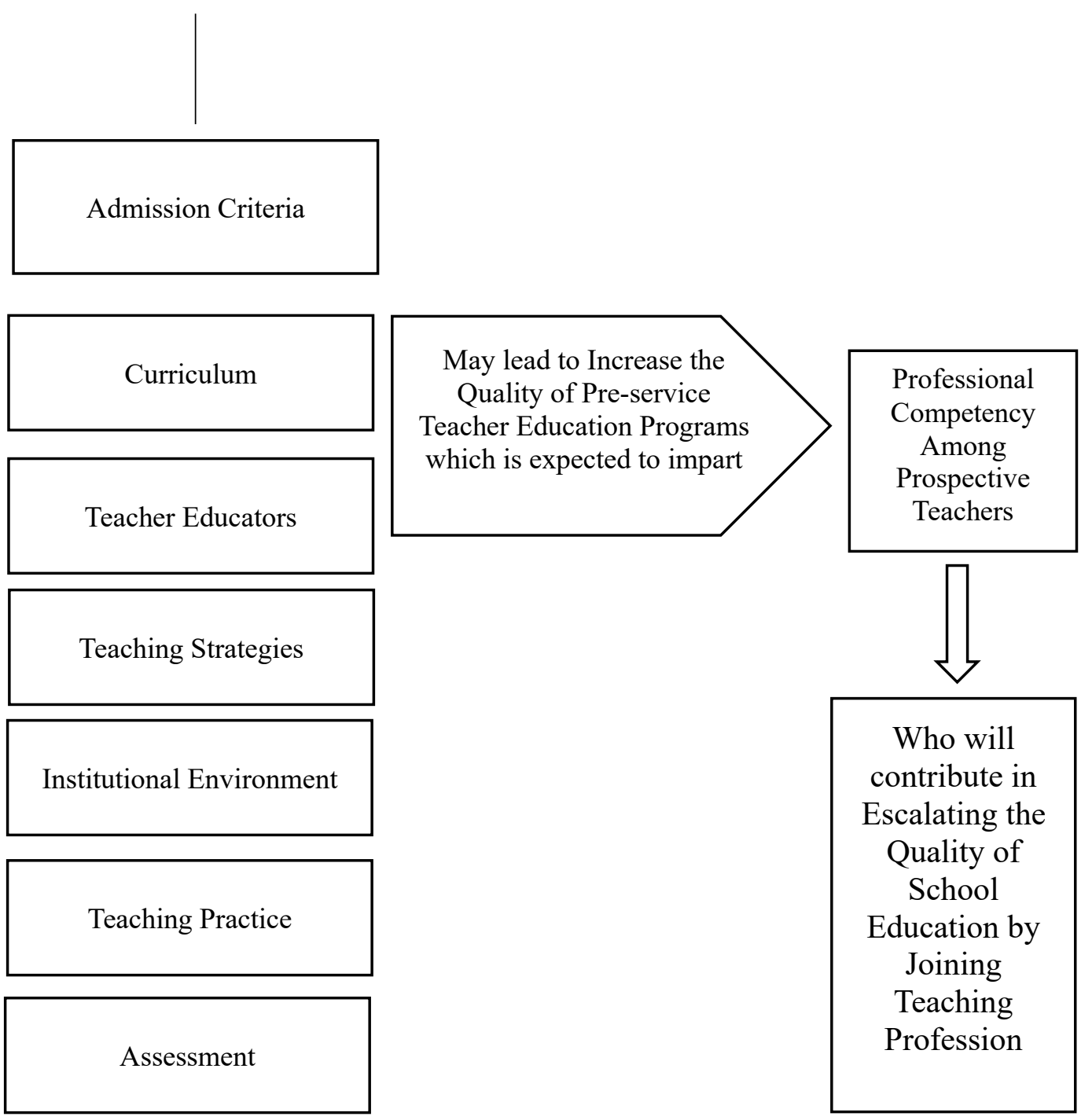

Figure 9. Hypothetical Model for Improvement of Pre-service Teacher Education Programs 


\section{REFERENCES}

Ahmed, M. (2009).Comparative Perspectives on Initial Primary Teacher Education and Training in England and Pakistan, An Unpublished PhD Thesis: University of Hull, UK.

Asian Development Bank ((1992). Appraisal of teacher training project in Islamic republic of Pakistan. Islamabad. Ministry of Education, Islamabad.

Academy for Educational Development, House 299, Street 19, E-7, Aurangzeb Road, Islamabad

Aga Khan University (2002). Research and policy dialogues on key issues in education. Discussion report, Karachi.

Barber, S.M. (2010). Education reform in Pakistan: This time it's going to be different.

Government of Pakistan (2006c). Quality and Standards in Education: Identifying Challenges and Solutions: Teacher Education and Assessments. Group Discussion. National Education Conference. Ministry of Education

Government of Pakistan (2002). Draft of National Plan of Action on Education For All (2000-2015). Ministry of Education, Islamabad.

Government of Pakistan (2002). Task Force on Improvement of Higher Education in Pakistan.

Government of Pakistan (2006a). Education in Pakistan: A white paper, document to debate and finalize the national education Policy, National Education Policy Review Team, Ministry of Education.

Government of Pakistan (2009). National Education Policy of Pakistan [p 33], Ministry of Education Islamabad.

Government of Pakistan (2004). Education Sector Reforms: Action Plan 2001-02-2005-06. Ministry of Education.

Government of Pakistan (2005). National educational assessment system, Ministry of Education, Islamabad

Gulzar, H.S., Bari, F., Ejaz, N. (2005). The role of NGO in Basic education in Pakistan.

Hayes, L.D. (1996). The Crisis of Education in Pakistan Delegate Brief, Ministry of Education. Lahore: Vanguard.

Hammond (2006). Constructing 21 st_Century Teacher Education. Journal of Teacher Education, Vol. 57, No. X, 1-15 (C) the American Association of Colleges for Teacher Education

Hammond (2010). Teacher education and the American future. Journal of Teacher Education, 61(1-2), 35-47.

Hoodbhoy(Ed.). (1998). Education and the State: fifty years of Pakistan. Karachi: Oxford Press.

Hoodbhoy(Ed.). (1998). Education and the State: fifty years of Pakistan. Karachi: Oxford Press.

Jaffer, R. (2005). Teacher Education. Donor Support to Education: Lessons Learned Meeting, 23-24 June, 2005. Islamabad. Final Report.

Musset, P. (2009), "Initial Teacher Education and Continuing Training Policies in a Comparative Perspective:Current Practices in OECD Countries and a Literature Review on Potential Effects", OECD Education Working Papers, No. 48, OECD Publishing retrieved

Panda \&Tewari (2009). Teacher Education. A.P.H Publishing Corporation Ansari road, Darya anj New Dehli.

Richard I. Arends (2007). L Learning To Teach, seventh edition. The McGraw Hill.

Rubio, (2009). Effective Teachers Professional And Personal Skills, ISSN 2171-9098 ENSAYOS. Revista de la Facultad de Educación de Albacete, $\mathrm{N}^{\circ}$ 24, 2009, (35-46) 35

Sultana, N. (2001). Elementary Education in Pakistan: current Status, Issues and Future Strategies. Multi-Donor Support Unit.

Soled, W.S (1995). Assessment, Testing and Evaluation in Teacher Education. (C) Abelex Publishing Corporation World Bank (2006). Program Document for a Proposed Third Punjab Education Sector Development Policy Credit. Report No. 35441-PK

World Bank (1996). Pakistan Improving Basic Education: Community Participation, System Accountability and Efficiency. Report No. 14960.http://www.btc.uob.edu.bh/details.aspx?id=aff71af9-f862-e211-b5dd0022191ecece \& gid =3 